\title{
Assessing accidental entanglement as a threat to the Mediterranean monk seal Monachus monachus
}

\author{
Alexandros A. Karamanlidis ${ }^{1, *}$, Evgenia Androukaki ${ }^{1}$, Stella Adamantopoulou ${ }^{1}$, \\ Archontia Chatzispyrou ${ }^{1}$, William M. Johnson ${ }^{2}$, Spyros Kotomatas ${ }^{1}$, \\ Anastasios Papadopoulos ${ }^{3}$, Vangelis Paravas ${ }^{1}$, Giorgos Paximadis ${ }^{4}$, \\ Rosa Pires $^{5}$, Eleni Tounta ${ }^{1}$, Panagiotis Dendrinos ${ }^{1}$
}

${ }^{1} \mathrm{MOm} /$ Hellenic Society for the Study and Protection of the Monk Seal, 18 Solomou Street, Athens 10682, Greece

${ }^{2}$ The Monachus Guardian, c/o M. Schnellmann, Wernerstraße 26, 3006 Bern, Switzerland

${ }^{3}$ Fisheries Research Institute, Nea Peramos, Kavala 64007, Greece

${ }^{4}$ WWF Greece, 26 Filellinon Street, Athens 10558, Greece

${ }^{5}$ Parque Natural da Madeira, Caminho do Meio, Funchal 9064-512, Madeira, Portugal

\begin{abstract}
The Mediterranean monk seal Monachus monachus is the most endangered seal in the world with $<600$ ind. currently surviving. The species faces a number of threats to its survival: accidental entanglement has been identified as one of the most important amongst them. Here we made the first attempt to systematically describe the nature of this threat and assess its impact on Mediterranean monk seal populations. We based our study on information from an extensive literature review, questionnaires carried out in various locations in Greece and necropsies performed in Greece and in the Madeira Islands, Portugal. Our results indicate that accidental entanglement has been, and still is, a major threat to the species in its main distribution area in the northeastern Mediterranean, and that this threat may increase throughout the seal's range. Accidental entanglement occurs mainly with fishing nets, and affects mostly sub-adult seals. Short-term conservation actions should include the identification of critical pupping sites and their protection through the establishment and enforcement of protective measures. A long-term course of action will require detailed knowledge of the causes of accidental entanglement of Mediterranean monk seals in fishing gear.
\end{abstract}

KEY WORDS: Endangered species · Mediterranean monk seal · Accidental entanglement · Conservation $\cdot$ Seal-fishery interactions $\cdot$ Greece $\cdot$ Madeira

\section{INTRODUCTION}

Accidental entanglement of marine mammals, turtles and sea birds in fishing gear remains a global problem of immense proportions, as thousands of animals representing non-target species fall victim to drift nets and other types of fishing gear (Alverson et al. 1994, Morizur et al. 1999, Murray 2004, Kiszka \& Muir 2007). Marine mammals, such as pinnipeds, may be particularly susceptible to severe population depletion (Read et al. 2006) because of their innate biological characteristics, being slow growing, long-lived animals, with low fecundity. Accidental entanglement has been reported to affect non-targeted populations of seals around the world (Baker et al. 1998, Hanni \& Pyle 2000, Page et al. 2004).

The 3 members of the genus Monachus are the only seals to exclusively inhabit tropical and low-latitude temperate waters; areas that have traditionally been subjected to the greatest pressure from humans. The Caribbean monk seal $M$. tropicalis is the only pinniped known to have become extinct and the Hawaiian monk seal M. schauinslandi is considered critically endangered (IUCN 2006). Accidental entanglement is considered a serious threat to the survival of monk seals (Henderson 2001). Once abundant throughout 
the Black Sea and the Mediterranean, and the coast and islands off northwest Africa, the Mediterranean monk seal $M$. monachus has been negatively affected by anthropogenic activities since antiquity (Johnson \& Lavigne 1999a) and is currently also critically endangered (IUCN 2006). Severe declines in abundance, especially in the last century, have largely reduced it to 3 isolated populations (Johnson et al. 2006): the largest population-ca. 250 to 350 ind.-survives in the northeastern Mediterranean, mainly at remote locations in the Ionian and Aegean Seas and the Cilician Basin (Güçlüsoy et al. 2004, Gucu et al. 2004, MOm 2007a). Approximately 100 to 150 ind., which comprise the single largest colony of the species, survive at Cap Blanc at the Western Sahara (González et al. 2002), and 30 to 35 ind. survive in the Madeira Islands (Pires et al. 2008) (Fig. 1a).

Since the initiation of efforts to protect the Mediterranean monk seal, a number of threats have been linked to the species' decline (Israëls 1992, Johnson \& Lavigne 1998, Johnson et al. 2006). The most important include deliberate killing due to competition with fisheries; human disturbance, e.g. habitat destruction and fragmentation; and accidental entanglement and drowning in fishing gear.

Despite the early recognition of the negative impact of accidental entanglement to the Mediterranean monk seal, there has been no systematic attempt to understand the causes, describe the nature and estimate the impact of this threat to the status of the species. In this study, we describe the nature of accidental entanglement and assess it as a threat to Mediterranean monk seal populations, discussing possible solutions to mitigate its future impact on the species.

\section{MATERIALS AND METHODS}

We based our study on data from 3 different sources: (1) a literature review, (2) data on Mediterranean monk seal bycatch collected through questionnaires carried out in Greece and (3) data from necropsies collected during the monitoring of Mediterranean monk seal populations in Greece and the Madeira Islands, Portugal.

Literature review. We carried out an extensive literature review in search of information describing the nature of accidental entanglement of Mediterranean monk seals in fishing gear and the extent of this interaction throughout the species' range. We restricted our search to information from the 18th century to the 1990s (first-hand field data from long-term monitoring projects became available in the 1990s) that was found in published and unpublished accounts included in the Annotated Bibliography on Mediterranean monk seals (Karamanlidis \& Johnson 2002).
Questionnaires on bycatch. In Greece, the Mediterranean monk seal is still widely distributed (Adamantopoulou et al. 1999). Due to the extent of the species' range within the country (i.e. $>15000 \mathrm{~km}$ of coastline and 3000 islands), the inaccessibility of its habitat and the resulting difficulties in surveying such a large area, we carried out questionnaires among professional fishers, whom we considered to be the group most likely to provide information on accidental entanglement of Mediterranean monk seals in fishing gear. The questionnaires collected information on (1) number, location, stage of development (as defined by Samaranch \& González 2000) and status (i.e. live or dead) of seals caught in fishing gear; and (2) types of fishing gear that the seals were caught in.

Based on information on the diving behaviour of Monachus monachus in the northeastern Mediterranean (Kiraç et al. 2002, Dendrinos et al. 2007) we considered 0 to $200 \mathrm{~m}$ as the depth range where the majority of seal-fishery interactions (and thus also entanglements) occur, and therefore carried out the questionnaires only amongst coastal fishers-the main professional group operating at these depths. Questionnaires were carried out within 1 protected and 2 unprotected areas in Greece: the main harbour of the island of Alonnisos in the National Marine Park of Alonnisos, Northern Sporades (NMPANS) in the northwestern Aegean; the main harbour of the island of Kalymnos; and several locations at the island of Zakinthos. The NMPANS is the only protected area in Greece dedicated to the protection of the Mediterranean monk seal; the local seal population is considered to be one of the most important in the eastern Mediterranean (Dendrinos et al. 1998). Protection is provided through the strict protection of the species' main pupping sites and the enforcement of fishery regulations. In the core zone of the NMPANS - which includes the island of Piperi, where the main pupping sites are located, and an area of 3 nautical miles (n miles) around it - all human activities, except scientific research and management of the island, are strictly prohibited. In addition, throughout the rest of the park, medium-sized commercial fisheries (purse seine and trawler fishing) are not allowed to operate closer than $1.5 \mathrm{n}$ miles from the coasts of all islands. Kalymnos is an island of the Dodecanese, in the southeastern Aegean Sea (Fig. 1b) with one of the biggest coastal fishing communities in Greece; Zakinthos is located in the southern Ionian Sea (Fig. 1b). When selecting the unprotected study sites, we considered one island in the Aegean and one in the Ionian Sea, both with a high number of monk seal sightings and large coastal fishing fleets. Based on available information (Adamantopoulou et al. 1999, DGMAF 2008) Kalymnos and Zakinthos fitted these considerations. 

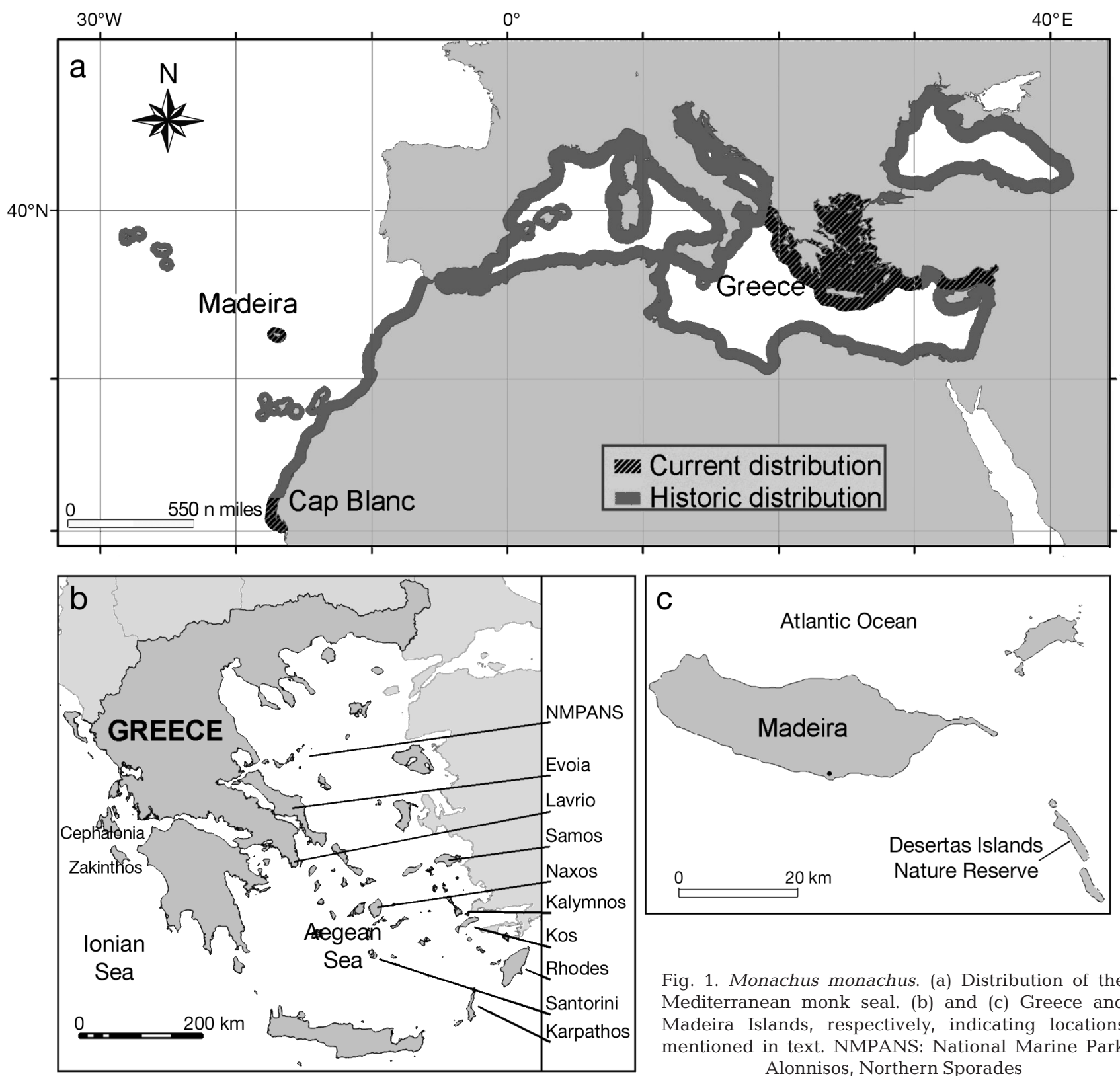

Fig. 1. Monachus monachus. (a) Distribution of the Mediterranean monk seal. (b) and (c) Greece and Madeira Islands, respectively, indicating locations mentioned in text. NMPANS: National Marine Park Alonnisos, Northern Sporades

Necropsies. To monitor Mediterranean monk seal populations in Greece, MOm/The Hellenic Society for the Study and Protection of the Monk seal, has been operating the National Rescue and Information Network (RINT) since 1991; RINT is alerted to the occurrence of live and dead seal sightings from throughout the country (Adamantopoulou et al. 1999).

In the Madeira Islands the status of the Mediterranean monk seal has been monitored by the Parque Natural da Madeira Service (PNMS) since 1988 (Neves \& Pires 1999, Pires et al. 2008). The monk seals on these islands are found mainly around the remote Desertas Islands (Fig. 1c), where they have been legally protected through the establishment of the Desertas Islands Nature Reserve (DINR) since 1990. The reserve boundary is defined by the $100 \mathrm{~m}$ isobath. The entire northern half of the park has partial reserve status, where the deployment of fishing nets is prohibited. The southern half includes the most important pupping sites for the species in the area (Karamanlidis et al. 2004), and has strict reserve status, where human activity - except traditional tuna fishing - is prohibited.

Depending on the state of decomposition, necropsies were performed on seals found dead in both Greece and Madeira, with all necessary samples being collected for the diagnosis of the cause of death. The 
necropsies were performed by trained staff according to specific necropsy protocols for pinnipeds (Winchell 1990) that have been adapted to the Mediterranean monk seal. Stages of development were determined according to Samaranch \& González (2000) and causes of death were assigned to the following categories

- Non-human induced death (NHID): no evidence of human involvement in the death of the animal (e.g. disease, drowning of pups due to bad weather conditions)

- Deliberate killing (DK): unequivocal evidence that the death was the result of deliberate human action (e.g. trauma from gunshot, harpoon or dynamite)

- Accidental death (AD): unequivocal evidence that the death was caused by non-deliberate human action (e.g. entanglement in fishing gear)

- Unknown cause of death (U): all cases where the cause of death could not be determined.

Based on criteria identified by Kuiken et al. (1994) we considered a seal to be accidentally entangled, if the following evidence was found:

(1) The animal was found entangled in nets and/or net ropes

(2) Traumatic lesions were found that are specific for capture in fishing gear, such as multiple, evenly spaced, parallel wounds on the skin

(3) Evidence was found that is consistent with death from immersion, such as fine persistent froth in the trachea and bronchi or bullae in the lung parenchyma

(4) Evidence of recent feeding, such as remains of partly digested or undigested prey, was found in the stomach.

\section{RESULTS}

\section{Literature review}

Mortality of Mediterranean monk seals from accidental entanglement in various types of fishing gear has been reported from most parts of the species' previous range. Monk seals have been accidentally ensnared on baited hooks in the Danube Delta (Schnapp et al. 1962), in tuna nets in France in the 1930s to 1940s (Cheylan 1974), in trammel gill nets in the Bay of Tunis (Ben Othman et al. 1971) and in unspecified nets on the coast of Spanish Sahara (now Western Sahara) in 1913 (Boettger 1951). In the Balearic Islands, it was reported that entanglement, mostly in tuna nets, accounted for 9 deaths and was second only to shooting as a source of human-induced mortality (Sergeant et al. 1978). In Algeria and Morocco, where 8 and 27 drownings were recorded, respectively, accidental entanglement was a major source of mortality up to the beginning of the 1990s (Anonymous 1990, Boutiba 1996).
Within the species' current distribution range, accidental entanglement has also been reported as a cause of mortality. Research conducted with the use of questionnaires in the Ionian islands of Greece in the early 1990 s indicated that accidental entanglement accounted for $23 \%$ of the 34 deaths recorded in the area (Panou et al. 1993). Similarly, research along the southern Aegean and western Mediterranean coasts of Turkey in the mid 1970s indicated that entanglement could almost rival shooting as a cause of mortality (Berkes et al. 1979); out of 7 known seal deaths, 3 could be attributed to drowning by entanglement. Prior to the establishment of the DINR, the extensive use of gill nets and the frequent drowning of monk seals in abandoned 'ghost' nets constituted a threat to the survival of the small surviving monk seal colony at the Desertas Islands of Madeira (Anselin \& van der Elst 1988, Neves 1998). In contrast, the monk seal colony at Cap Blanc appears to have been largely shielded from the effects of accidental entanglement up until 1987, because of warfare and political instability that limited fishing in the region.

Of the different types of fishing gear in which Mediterranean monk seals are reported to have been ensnared (i.e. baited hooks and long-lines, tuna nets, gill nets), they appear to be most vulnerable to entanglement in static gear and discarded nets in coastal areas (Harwood 1987, Panou et al. 1987, Israëls 1992). There is no evidence to suggest that in the past any age or sex category was particularly vulnerable (Anonymous 1990).

\section{Questionnaires}

At the main harbour of the island of Alonnisos in the Aegean Sea, 25 questionnaires were completed (covering approximately $30 \%$ of the total population of fishers). All fishers interviewed worked mainly within the boundaries of the NMPANS. From the 21 responses regarding accidental entanglement, only one reported to have caught a sub-adult monk seal in a long-line that subsequently managed to free itself (Table 1). Forty questionnaires were completed at the main harbour of the island of Kalymnos (covering ca. $30 \%$ of the total population of fishers). All but one of the fishers interviewed was based at Kalymnos, although their fishing operations extended throughout the central and southeastern Aegean. Of the 40 responses regarding accidental entanglement, 4 reported to have captured monk seals (a total of 5 seals: 4 sub-adults, 1 adult). Four of these monk seals were found drowned in static gear (i.e. gill nets), while 1 juvenile caught in a longline managed to free itself (Table 1). At the island of Zakinthos 20 questionnaires were completed (covering 
approximately $35 \%$ of the total population of fishers). All fishers interviewed worked mainly around the island of Zakinthos, but 4 also extended their fishing operations to Cephalonia in the north and the western coasts of the Peloponnese in the east. Five fishers reported having caught a total of 7 seals in their gill nets. All of these were sub-adults and only 2 were alive and subsequently freed (Table 1).

\section{Necropsies}

From 1991 to 2007, 200 dead monk seals were reported to the RINT in Greece; in 96 cases full necropsies were carried out. In 104 cases no necropsy was carried out, either because the recovered carcass was already too decomposed or because MOm was informed too late and the carcass had already been disposed of. Accidental entanglement in fishing gear was determined as the cause of death in 7 female subadult Mediterranean monk seals, found in Zakinthos ( $\mathrm{n}=2$ ), Naxos, Samos, Evoia $(\mathrm{n}=2)$ and Lavrio. It was the second most frequently recorded human-related cause of mortality and the 4 th overall (NHID, DK and AD accounted for 40,16 , and $8 \%$ of all cases, respectively; the cause of death could not be determined in $36 \%$ of the cases) (Table 2). Entanglement appeared to affect mainly sub-adult individuals $(46 \%)$. In contrast, the most frequently recorded mortality cause in adults was deliberate killing (50\%) and NHID in pups (93\%). No death through accidental entanglement was recorded within the NMPANS.

In the Madeira Islands (1989 to 2007), PNMS recorded 7 dead monk seals (5 pups, 2 sub-adults) and 1 subadult hooded seal Cystophora cristata. One monk seal pup and the sub-adult hooded seal died of NHID, while the rest died of unknown causes. No case of accidental entanglement was recorded.

\section{DISCUSSION}

Effective protection and management of endangered species requires the detailed understanding of the causes, nature and magnitude of the mortality factors that affect it. In the case of the critically endangered Mediterranean monk seal, the species' low population numbers, its retiring nature and the inaccessibility of its habitat have hampered scientific research that could provide insights into such issues (Güçlüsoy et al. 2002). In addition, research related to mortality causes faces inherent difficulties, such as bias in data collection and statistical errors in data analysis, and is therefore capable of delivering only an approximation of the true nature of the phenomenon. Considering these difficulties, we believe that the numbers of seals caught accidentally in fishing gear recorded during our study represent a minimum of animals actually caught.

Table 1. Information from questionnaires on accidental ensnarement of Mediterranean monk seals in fishing gear. n.a.: information not available, NMPANS: National Marine Park of Alonnisos, Northern Sporades

\begin{tabular}{|c|c|c|c|c|}
\hline $\begin{array}{l}\text { Number of } \\
\text { seals caught }\end{array}$ & $\begin{array}{c}\text { Type of } \\
\text { fishing gear }\end{array}$ & Location & $\begin{array}{c}\text { Seal development } \\
\text { stage }\end{array}$ & $\begin{array}{c}\text { Seal } \\
\text { status }\end{array}$ \\
\hline 1 & Long-line & NMPANS & Sub-adult & Alive \\
\hline 1 & Gill net & Rhodes & Sub-adult & Dead \\
\hline 1 & Gill net & Karpathos & Sub-adult & Dead \\
\hline 1 & Gill net & n.a. & Adult & Dead \\
\hline 1 & Gill net & n.a. & Sub-adult & Dead \\
\hline 1 & Long-line & Kos & Sub-adult & Alive \\
\hline 1 & Gill net & Zakinthos & Sub-adult & Dead \\
\hline 1 & Gill net & Cephalonia & Sub-adult & Alive \\
\hline 1 & Gill net & n.a. & Sub-adult & Alive \\
\hline 1 & Gill net & W Zakinthos & Sub-adult & Dead \\
\hline 1 & Gill net & S Cephalonia & Sub-adult & Dead \\
\hline 1 & Gill net & N Cephalonia & Sub-adult & Dead \\
\hline 1 & Gill net & Zakinthos & Sub-adult & Dead \\
\hline
\end{tabular}

Table 2. Monachus monachus. Necropsies carried out in Greece (1991-2007) and causes of death determined. Ensnarement: accidental ensnarement in fishing gear

\begin{tabular}{|ccccc|}
\hline Year & $\begin{array}{c}\text { Deliberately } \\
\text { killed }\end{array}$ & Ensnarement & $\begin{array}{c}\text { Non-human- } \\
\text { induced death }\end{array}$ & $\begin{array}{c}\text { Unknown } \\
\text { cause }\end{array}$ \\
\hline 1991 & 0 & 0 & 1 & 0 \\
1992 & 0 & 0 & 2 & 0 \\
1993 & 2 & 1 & 0 & 0 \\
1994 & 1 & 0 & 5 & 0 \\
1995 & 0 & 1 & 2 & 1 \\
1996 & 1 & 0 & 3 & 2 \\
1997 & 1 & 0 & 4 & 3 \\
1998 & 1 & 0 & 1 & 1 \\
1999 & 2 & 0 & 4 & 4 \\
2000 & 1 & 1 & 3 & 2 \\
2001 & 0 & 2 & 2 & 4 \\
2002 & 1 & 0 & 2 & 4 \\
2003 & 2 & 0 & 0 & 2 \\
2004 & 1 & 0 & 3 & 3 \\
2005 & 0 & 1 & 1 & 2 \\
2006 & 2 & 0 & 2 & 35 \\
2007 & 0 & 1 & 4 & 4 \\
Total & 15 & 7 & 39 & \\
\hline
\end{tabular}


Accidental entanglement has posed a threat to the species since antiquity (Johnson \& Lavigne 1999a, Johnson 2004). Although it is impossible-due to the constraints mentioned above - to accurately estimate the impact of accidental entanglement on the status of the species, the results of our literature review indicate that this mortality cause has probably played an important role in the extirpation of the species from several areas of its previous distribution, and that in some cases accidental entanglement could have rivalled deliberate killing as the most important human-related mortality cause. A similar picture arises from the analysis of the data obtained from the questionnaires and the necropsies carried out in Greece, where accidental entanglement and subsequent drowning of seals has been recorded in areas where there is no effective protection of important pupping sites and no fishing regulations are in force. Despite the earlier belief that no age class was particularly vulnerable to this type of mortality (Anonymous 1990), the results of the research in Greece indicate that sub-adult monk seals may be especially prone to entanglement. This fact is corroborated by circumstantial evidence from the Aegean coast of Turkey, where accidental entanglement in fishing nets has been blamed for several recent deaths of pups and sub-adults (Veryeri et al. 2001). We speculate that individuals of this age class might be less cautious and less experienced than adults when approaching nets. Considering the limited amount of data collected to date, further monitoring is required in order to substantiate this hypothesis.

Regarding the type of fishing gear mostly affecting Mediterranean monk seals in Greece, our evidence suggests that static nets pose the highest threat, as all animals reported as caught in long-lines subsequently managed to free themselves. This finding is in accordance with findings in the past throughout the species' range (Harwood 1987, Panou et al. 1987, Israëls 1992).

Accidental entanglement is currently not a threat to the Mediterranean monk seal in the Madeira Islands. This is due to the prohibition of the use of gill nets throughout the entire Madeira Islands in combination with the strict protection and the fishing regulations enforced around the main pupping sites of the species at the Desertas islands. The results of the present study justify the decision of PNMS to provide incentives to local fishers to switch from using static fishing nets to using alternative forms of fishing, such as long-lines (Pires \& Neves 2001). Considering, however, the fact that the species is showing encouraging signs of recovery in its repopulation of the main island of Madeira, and that interactions of Mediterranean monk seals with fisheries have increased (Pires et al. 2008), accidental entanglements might occur in the near future.
At Cap Blanc up to the 1990s accidental entanglement was considered not to pose a threat to the survival of the species due to the political instability in the region. With the resumption of both industrial and artisanal fishing in the area, however, (Zeeberg et al. 2006), the risk of accidental entanglement has returned in force. Although no deaths have been directly linked to fishery interactions, there is concern that seals may fall victim to entanglement in the future (Anonymous 1990, González et al. 2002).

Considering the low population levels of Mediterranean monk seals, our study indicates that accidental entanglement has represented and still does represent a threat to the survival of the species in a large part of its range in the northeastern Mediterranean. Furthermore, considering the fact that human pressure on coastal ecosystems in the Mediterranean basin in the near future will increase (Johnson \& Lavigne 1999b) and that fishing pressures might, in turn, increase in response to regional demand, it is probable that the threat of accidental entanglement on the survival of the species will also increase throughout its range, unless appropriate conservation measures are taken.

In addressing the problem of accidental entanglement, one needs to understand the reasons why Mediterranean monk seals raid fishing gear. In this respect, 2 separate assumptions have been advanced to explain the seals' behaviour. The first relates to the innate tendency of every species to conserve energy and seek food at the most convenient of places, while the second relates to the overfishing of coastal areas within the species' distribution range (Johnson \& Karamanlidis 2000). There is insufficient evidence to substantiate any of these theories; this shortcoming in the understanding of the causes of accidental entanglement is currently addressed by an EU-funded LIFE project (MOm 2007b).

Regardless of the reasons that drive Mediterranean monk seals towards fishing nets, and considering the urgency for conservation measures that will effectively protect the species, 2 protection measures are most likely to be considered in the near future: the use of acoustic deterrents and the establishment and enforcement of fishing regulations.

Taking into account the mixed long-term results acoustic deterrents have had in driving seals away from fishing nets, and their cost (Pemberton \& Shaughnessy 1993, Yurk \& Trites 2000, Fjälling et al. 2006), as well as the large number of fishers and the large extent of the area in which such conservation actions would have to take place, we do not believe that the use of such devices represents a viable solution to the problem of accidental entanglement of Mediterranean monk seals in fishing gear. 
In contrast, fishing regulations at and around critical pupping sites, such as those currently in force at the NMPANS and DINR (i.e. no fishing allowed at a distance of $3 \mathrm{n}$ miles around the main pupping sites at the NMPANS, no fishing allowed around the main pupping sites within the area between the coast and the $100 \mathrm{~m}$ isobath at the DINR), have managed to eliminate the threat of accidental entanglement to the monk seal populations in both areas.

\section{CONCLUSIONS}

Mediterranean monk seals are currently threatened with extinction. Amongst the array of threats that jeopardise their survival, accidental entanglement ranks as one of the most important. Conservation actions that aim to mitigate the effects of this threat should include the identification of important pupping sites of the species and their effective protection through specific human activity and fishing regulations (i.e. creation of marine protected areas, MPAs). Such conservation actions would maximise the survival chances of subadult seals, while at the same time increasing fish stocks and providing fishing opportunities to local communities through spillover of exploitable fishes from the protected areas (McClanahan \& Mangi 2000). Thus MPAs are the most realistic and viable short-term solution to the problem of accidental entanglement of Mediterranean monk seals in fishing gear.

However, an effective and long-term solution to the problem cannot be provided unless the causes of this threat are fully understood. Further research into the causes of accidental entanglement of Mediterranean monk seals in fishing gear should be one of the outstanding research priorities in the near future.

Acknowledgements. RINT's operation and necropsies in Greece have been carried out with the financial support of EU projects Contract Nos. 4-3010(92)7829 and B4-3040/95/009/ AO/D2, LIFE/Nature project LIFE96NAT/GR/ 3225, LIFE00 NAT/GR/7248 and the MOFI LIFE project (LIFE05NAT/ GR/000083). MOm expresses its gratitude towards all members of RINT and the volunteers that assisted in this work. The questionnaire part of the study in Greece was carried out as part of the MOFI LIFE project (LIFE05NAT/GR/000083). MOm thanks the presidents of the fishing cooperatives of Kalimnos and Zakinthos, Mr. G. Katsotourchis and N. Paraschis, who assisted greatly in organising the questionnaire study. We thank Andrew Cunningham and 3 anonymous reviewers for their constructive comments in the preparation of this document. Lastly, MOm thanks all fishers who participated in the questionnaires, and the Hellenic Ministry of Rural Development and Food for its support and for providing research permits. In the Madeira Islands, necropsies were performed with the invaluable assistance of the Seal Rehabilitation and Research Centre, the Regional Secretary of Fisheries, the City Council of Funchal and the Regional Veterinary Lab, as well as the Institute of Virology of the University of Rotterdam in Holland. The Marine Mammal Fisheries Network (http://groups.yahoo.com/group/Marine_MammalFisheries_Network) was instrumental in coordinating actions in preparing this manuscript.

\section{LITERATURE CITED}

Adamantopoulou S, Androukaki E, Kotomatas S (1999) The distribution of the Mediterranean monk seal in Greece based on an information network. Contr Zoogeogr Ecol East Med Reg 1:399-404

Alverson DL, Freeberg MH, Pope JG, Murawski SA (1994) A global assessment of fisheries bycatch and discards. FAO Fish Tech Pap 339:1-233

Anonymous (1990) Urgent action meeting for safeguarding the Mediterranean monk seal as a species, 10 to 11 December 1990. Texel 1-11

Anselin A, van der Elst M (eds) (1988) Monk seal bulletin, Vol 7. Institut Royal des Sciences Naturelles de Belgique, Brussels, p 1-5

Baker JR, Jepson PD, Simpson VR, Kuiken T (1998) Causes of mortality and non-fatal conditions among grey seals (Halichoerus grypus) found dead on the coasts of England, Wales and the Isle of Man. Vet Rec 142:595-601

Ben Othman S, Mokhtar F, Quignard JP (1971) Presence d' un phoque moine Monachus monachus (Hermann, 1779) dans le Golfe de Tunis. Bull Inst Natl Sci Tech Oceanogr Peche Salammbo 2:267

Berkes F, Anat H, Esenel M, Kislalioglu M (1979) Distribution and ecology of Monachus monachus on Turkish coasts. In: Ronald K, Duguy R (eds) First Int Conf on the Mediterranean monk seal, Rhodes, Greece, 2-5 May 1978. Pergamon Press, Oxford, p 113-128

Boettger CR (1951) Notizen zur Verbreitung und ueber die Verwandtschaftsbeziehungen der Moenchsrobbe (Monachus albiventer Boddaert). Zool Anz 147:303-310

Boutiba Z (1996) Disappearing species: the case of the monk seal in Algeria. In: Swearingen WD, Bencherifa A (eds) The North African environment at risk. Westview Press, Boulder, CO and Oxford, p 191-204

Cheylan G (1974) Quand il y avait des phoques en Provence. Le Chasseur Francais (926) April 1974:48

Dendrinos P, Tounta E, Kotomatas S (1998) Status and conservation of the monk seal population in the National Marine Park of Alonnissos - N. Sporades, Greece. In: World Mar Mamm Sci Conf, Workshop on the Biology and Conservation of the World's Endangered Monk Seals, Monaco, 19-20 January 1998. The Society for Marine Mammalogy \& The European Cetacean Society, La Rochelle, p 14

> Dendrinos P, Karamanlidis AA, Androukaki E, McConnell BJ (2007) Diving development and behavior of a rehabilitated Mediterranean monk seal (Monachus monachus). Mar Mamm Sci 23:387-397

DGMAF (Directorate-General for Maritime Affairs and Fisheries (2008) Facts and figures on the EU fishing fleet. http://ec.europa.eu/fisheries/fleetstatistics/index.cfm? ctyCode=GRC (accessed 25 January 2008)

Fjälling A, Wahlberg M, Westerberg H (2006) Acoustic harassment devices reduce interaction in the Baltic salmon-trap, net fishery. ICES J Mar Sci 63:1751-1758

González LM, Cedenilla MA, Larrinoa PF, Layna JF, Aparicio F (2002) Changes in the breeding variables of the Mediterranean monk seal (Monachus monachus) colony of Cabo Blanco Peninsula after a mass mortality episode. Mammalia 6:173-182 
Güçlüsoy H, Johnson WM, Karamanlidis AA (2002) Mediterranean monk seal behaviour: Can we afford to discard anecdotal accounts? The Monachus Guardian 5(2): November 2002. Available at: www.monachusguardian.org/mguard10/1023 perspe.htm (accessed: 30th June 2008)

Güçlüsoy H, Kiraç CO, Veryeri NO, Savas Y (2004) Status of the Mediterranean monk seal, Monachus monachus (Hermann, 1779) in the coastal waters of Turkey. EU J Fish Aquat Sci 21:201-210

Gucu AC, Gucu G, Orek H (2004) Habitat use and preliminary demographic evaluation of the critically endangered Mediterranean monk seal (Monachus monachus) in the Cilician Basin (Eastern Mediterranean). Biol Conserv 116:417-431

Hanni KD, Pyle P (2000) Entanglement of pinnipeds in synthetic materials at southeast Farallon Island, California, 1976-1998. Mar Pollut Bull 40:1076-1081

Harwood J (1987) Population biology of the Mediterranean monk seal in Greece. Contract ENV 853 UK, DG XII. A report on research conducted by the Natural Environment Research Council's Sea Mammal Research Unit with financial assistance from the Commission of the European Communities and the International Fund for Animal Welfare, Cambridge, p 1-72

Henderson JR (2001) A pre- and post-MARPOL Annex V summary of Hawaiian monk seal entanglements and marine debris accumulation in the northwestern Hawaiian Islands, 1982-1998. Mar Pollut Bull 42:584-589

Israëls LDE (1992) Thirty years of Mediterranean monk seal protection: a review. Mededelingen 28:1-65

IUCN (2006) 2006 IUCN Red List of threatened species. Available at: www.iucn.org/themes/ssc/redlist2006/ redlist2006.htm (accessed 20th September 2007)

Johnson WM (2004) Monk seals in post-classical history. The role of the Mediterranean monk seal (Monachus monachus) in European history and culture, from the fall of Rome to the 20th century. Mededelingen 39:1-91

Johnson WM, Karamanlidis AA (2000) When fishermen save seals. The Monachus Guardian 3(1): May 2000. Available at: www.monachus-guardian.org/mguard05/05covsto.htm (accessed: 30th June 2008)

Johnson WM, Lavigne DM (1998) The Mediterranean monk seal. Conservation guidelines. Multilingual edition. International Marine Mammal Association, Guelph, p 1-152

Johnson WM, Lavigne DM (1999a) Monk seals in antiquity. The Mediterranean monk seal (Monachus monachus) in ancient history and literature. Mededelingen 35:1-101

Johnson WM, Lavigne DM (1999b) Mass tourism and the Mediterranean monk seal: the role of tourism in the decline and possible future extinction of Europe's most endangered marine mammal, Monachus monachus. The Monachus Guardian 2:62-81

Johnson WM, Karamanlidis AA, Dendrinos P, de Larrinoa PF and others (2006) Monk seal fact files. Biology, behaviour, status and conservation of the Mediterranean monk seal, Monachus monachus. The Monachus Guardian. Available at: www.monachus-guardian.org/factfiles/medit01.htm (accessed: 30th June 2008)

Karamanlidis AA, Johnson WM (eds) (2002) Annotated bibliography on Mediterranean monk seals (Monachus monachus). Version 1.0. The Monachus Guardian. Available at: www.monachus-guardian.org (accessed: 30th June 2008)

Karamanlidis AA, Pires R, Silva NC, Neves HC (2004) The availability of resting and pupping habitat for the Critically Endangered Mediterranean monk seal Monachus monachus in the archipelago of Madeira. Oryx 38: 180-185
Kiraç CO, Savas Y, Güçlüsoy H, Veryeri NO (2002) Observations on diving behaviour of free ranging Mediterranean monk seals Monachus monachus on Turkish coasts. The Monachus Guardian 5: May 2002. Available at: www.monachus-guardian.org/mguard09/09scien2.htm (accessed: 30th June 2008)

Kiszka J, Muir C (eds) (2007) Incidental catch of non-targeted marine species in the Western Indian Ocean: problems and mitigation measures. Workshop Proceedings. 13-15th November 2006. Mayotte, p 1-111

Kuiken T, Simpson VR, Allchin CR, Bennett PM and others (1994) Mass mortality of common dolphins (Delphinus delphis) in south-west England due to incidental capture in fishing gear. Vet Rec 134:81-89

McClanahan TR, Mangi S (2000) Spillover of exploitable fishes from a marine park and its effects on the adjacent fishery. Ecol Appl 10:1792-1805

MOm (2007a) Status of the Mediterranean monk seal (Monachus monachus) population in Greece. Report to the Hellenic Ministry of Rural Development and Food. Athens, January 2007

MOm (2007b) Monk seal and fisheries: mitigating the conflict in Greek seas. LIFE05NAT/GR/000083. Project's interim report to the European Commission, July 2005-June 2007. MOm, Athens

Morizur Y, Berrow SD, Tregenza NJC, Couperus AS, Pouvreau $S$ (1999) Incidental catches of marine-mammals in pelagic trawl fisheries of the northeast Atlantic. Fish Res 41:297-307

Murray KT (2004) Magnitude and distribution of sea turtle bycatch in the sea scallop (Placopecten magellanicus) dredge fishery in 2 areas of the northwestern Atlantic Ocean, 2001-2002. Fish Bull (Wash DC) 102:671-681

Neves HC (1998) Preliminary findings of the feeding behavior and general ecology strategy of the Mediterranean monk seal Monachus monachus (Pinnipedia: Monachinae) on the Desertas Islands. Bol Mus Mun Funchal 4:263-271

Neves HC, Pires R (1999) O Lobo Marinho no Arquipelago da Madeira. Parque Natural da Madeira, Funchal, p 1-76

Page B, McKenzie J, McIntosh R, Baylis A and others (2004) Entanglement of Australian sea lions and New Zealand fur seals in lost fishing gear and other marine debris before and after government and industry attempts to reduce the problem. Mar Pollut Bull 49:33-42

Panou A, Beudels R, Harwood J (1987) Interactions between monk seals and fishermen. In: Harwood J (ed) Population biology of the Mediterranean monk seal in Greece. Natural Environmental Research Council, Sea Mammal Research Unit, Cambridge, p 45-50

Panou A, Jacobs J, Panos D (1993) The endangered Mediterranean monk seal Monachus monachus in the Ionian Sea, Greece. Biol Conserv 64:129-140

Pemberton D, Shaughnessy PD (1993) Interaction between seals and marine fish-farms in Tasmania, and management of the problem. Aquat Conserv Mar Freshw Ecosyst 3:149-158

Pires R, Neves HC (2001) Mediterranean monk seal Monachus monachus conservation: a case study in the Desertas Islands. Mammalia 65:301-308

Pires R, Neves HC, Karamanlidis AA (2008) Conservation status and priorities of the critically endangered Mediterranean monk seal Monachus monachus in the archipelago of Madeira. Oryx 42(2):278-285

- Read AJ, Drinker P, Northridge S (2006) Bycatch of marine mammals in US and global fisheries. Conserv Biol 20:163-169

Samaranch R, González LM (2000) Changes in morphology 
with age in Mediterranean monk seals (Monachus monachus). Mar Mamm Sci 16:141-157

Schnapp B, Hellwing S, Ghizelea G (1962) Contributions to the knowledge of the Black Sea seal (Monachus monachus) Herm. Trav Mus Hist Nat 'Grigore Antipa' 3:383-400

Sergeant D, Boulva J, Berkes F, Ronald K (1978) Recent status of Monachus monachus, The Mediterranean monk seal. Mediterr Monk Seal Biol Conserv 14:259-287

Veryeri O, Güçlüsoy H, Savas H (2001) Snared and drowned. The Monachus Guardian 4(1): May 2001. Available at: www.monachus-guardian.org/mguard07/07covsto.htm

Editorial responsibility: Andrew Cunningham,

London, UK (accessed: 30th June 2008)

Winchell JM (1990) Field manual for phocid necropsies (specifically Monachus schauinslandi). US Department of Commerce, NOAA Tech Memo, NOAA-TM-NMFSSWFSC-146, Honolulu, HI

Yurk H, Trites AW (2000) Experimental attempts to reduce predation by harbour seals on out-migrating juvenile salmonids. Trans Am Fish Soc 129:1360-1366

Zeeberg J, Corten A, de Graaf E (2006) Bycatch and release of pelagic megafauna in industrial trawler fisheries off Northwest Africa. Fish Res 78:186-195

Submitted: November 4, 2007; Accepted: March 17, 2008 Proofs received from author(s): July 10, 2008 